\title{
Association Between Oral Diseases And Sociodemographic Variables In Children And Adolescents With Cancer
}

\author{
Deise Berger Velten ( $\nabla$ deisebv82@gmail.com )

\section{Eliana Zandonade} \\ Universidade Federal do Espírito Santo \\ Maria Helena Monteiro de Barros Miotto \\ Universidade Federal do Espírito Santo
}

Federal University of Espírito Santo https://orcid.org/0000-0002-8750-0782

\section{Research article}

Keywords: Oral Health, Child, Medical, Oncology

Posted Date: February 21st, 2020

DOI: https://doi.org/10.21203/rs.2.24197/v1

License: (c) (i) This work is licensed under a Creative Commons Attribution 4.0 International License. Read Full License 


\section{Abstract}

Objective

To evaluate the association between sociodemographic variables and oral diseases in children and adolescents with cancer receiving treatment at the "Nossa Senhora da Glória” State Children Hospital (HEINSG) - Vitória - ES.

Method

This is a cross-sectional study, in which 51 subjects were evaluated before or three days after the start of chemotherapy from April 2013 to April 2014.

Results

When the study participants were examined the prevalence of dental caries was $25.4 \%$, xerostomia presented with a frequency of $31 \%$. Other diseases were also observed at lower frequency, such as mucositis, candidiasis and thrush. Caries was significantly associated with poor oral hygiene (OR: 0,114; $p-0.016)$ and low maternal schooling (OR: 0,188; $p$ 0.021).

Conclusion

Some subjects had oral disease before starting chemotherapy; therefore, they were more likely of developing oral manifestations during treatment. The participation of the dental surgeon in the multidisciplinary team of cancer treatment is important to evaluate the oral health status of individuals before and during treatment, thus developing an appropriate treatment plan to prevent or reduce the occurrence of oral manifestations during therapy.

Clinical Relevance

This study showed and reaffirmed the importance of an evaluation of the oral condition prior to chemotherapy treatment and also the need for a dental surgeon in the team of professionals who accompany cancer patients to treat caries lesions and remove foci of infection, preventing thus the appearance of oral manifestations that may delay chemotherapy, generating unnecessary suffering for these patients.

\section{Introduction}

Oral diseases are currently a major public health problem, not only due to their high prevalence, but also to their impact on individual and collective levels in terms of pain, discomfort, functional and social limitations, which ultimately affects quality of life of individuals ${ }^{1}$.

Child cancer presents peculiar histopathological features. Therefore, it should be studied separately from diseases that affect adults, especially with regard to clinical behavior 2,3 .

In Brazil and worldwide, child cancer is considered a public health problem due to the high mortality rate, the high financial cost of detection, diagnosis and treatment, as well as the wasted economic resources resulting from reduction of human labor potential ${ }^{4}$.

The percentage of pediatric tumors observed in Brazilian population-based cancer records (RCBP) is close to $3 \%$. For Brazil, according to 2014 estimates also valid for 2015 , there will be about 11,840 new cases of cancer in children and adolescents up to the age of $19^{3}$. 
There are three main forms of treatment today for cancer: surgery, chemotherapy and radiotherapy. Surgery is an isolated procedure for malignant tissue and chemotherapy and radiotherapy cause the destruction of rapidly multiplying cells 5 ; however, they do not differentiate neoplastic cells from normal cells that also multiply rapidly, such as those of the oral mucosa ${ }^{6,7}$.

There may be clinically important side effects in the oral cavity of patients undergoing antineoplastic treatment, such as mucositis, xerostomia ${ }^{8}$, gingivitis, candidiasis, dental caries, cellulitis and mucosal eruptions ${ }^{9}$.

Dentistry based on health promotion directed to a specific child population, such as patients with malignant neoplasia, plays an indispensable role in the restoration of general health and, consequently, the quality of life of these children ${ }^{1}$.

The clinical examination of pediatric oncology patients should be performed by dental professionals as soon as they have their disease diagnosed, so that the dental treatment is performed before the oncologic treatment, since these professionals play a fundamental role in the control and treatment of oral cavity alterations resulting from the antineoplastic treatment ${ }^{10}$. Thus, the aim of this study was to evaluate the existence of associations between oral diseases and sociodemographic variables in children and adolescents diagnosed with cancer undergoing chemotherapy treatment at HEINSG in the city of Vitória - ES.

\section{Methods}

This cross-sectional study was conducted at HEINSG, with all patients being covered by SUS and is the only reference center of the state public system for oncology treatment for children and adolescents. Children and adolescents up to the age of 18 years and 364 days, who received the first diagnosis of malignant neoplasia, who underwent chemotherapy treatment between April 2013 and April 2014, were selected to participate in the study. In this study, individuals aged 1018 years were considered adolescents as defined by the World Health Organization (WHO), which considers adolescence as the period in which subjects are aged 10-19 years.

Individuals were approached when they received the cancer diagnosis or up to 3 days after starting chemotherapy.

The standardized interview method was used for the application of semistructured scripts during the approach of individuals and / or caregivers to obtain information about sociodemographic characteristics.

Information regarding the diagnosis and type of therapy indicated for each individual was collected in the patients' records.

After the conclusion of the interview, individuals were submitted to a clinical examination to collect information about the oral condition. Dental caries, gingivitis, xerostomia, mucositis, oral candidiasis, herpes simplex and canker sores were evaluated.

Visual clinical examination was performed by a trained dental professional who was a researcher at the HEINSG facilities. Standardization was established to perform the clinical examination respecting the individuals' conditions, the physical location, the environmental conditions, the diagnostic criteria and the recording of the exam data ${ }^{11}$.

Dental caries examination was performed according to criteria of the National Oral Health Survey in Brazil with some modifications due to the specificity of the target public. The different dental spaces, both in the case of deciduous and permanent teeth, were approached from one to the other systematically starting from the upper arch (tooth 18 up to 28,55 to 65 ), followed by the lower arch (tooth 38 up to $48 ; 75$ to 85 ). A dental element was considered present in the oral cavity when it presented any visible part, even if a small part of its crown. In cases where permanent and deciduous teeth occupy the same space, only the condition of the permanent tooth was recorded ${ }^{11}$. 
The following codes were used to diagnose dental caries: letters to characterize deciduous teeth and numbers for permanent teeth:

- Code A or 0 - healthy tooth - there is no evidence of caries. Early stages of the disease are not taken into account. - Code B or 1 - decayed tooth - Dental caries evident in dentin, or dentin and pulp. Stains present in grooves and fissures and smaller cavities present in enamel and dentin were disregarded. Teeth restored, but with caries infiltration.

- Code $\mathrm{C}$ or 2 - restored tooth but with caries - there are one or more restorations and at the same time one or more areas are decayed. There is no distinction between primary and secondary caries ${ }^{13}$.

The diagnosis of xerostomia was made by means of a test that consisted of measuring the saliva produced, without stimulus, for one minute, in a millimeter plastic container $(0$ to $3 \mathrm{ml})$. The amount of saliva commonly secreted by people without stimuli is $0.3 \mathrm{ml} / \mathrm{min}$, if secretion less than or equal to $0.1 \mathrm{ml} / \mathrm{min}$ occurs, it is characterized as hyposalivation 12 .

When measurement of less than $0.3 \mathrm{ml} / \mathrm{min}$ of saliva in the sialometric test was obtained, and in addition symptoms described in any of the severity degrees of the scale used to quantify xerostomia as an adverse effect proposed by the World Health Organization (Table 1) were present, xerostomia was considered present and when in the test, measurement higher than $0.3 \mathrm{ml} / \mathrm{min}$ was observed, no symptomatology was also observed, and xerostomia was considered absent ${ }^{13}$.

Painting 1 - Quantification of xerostomia as adverse effect according to WHO

\section{XEROSTOMIA SEVERITY LEVELS} Level Symptomatic (thick or little saliva), no significant dietary changes, unstimulated saliva production $>0.2 \mathrm{ml} /$
min;

Level Symptomatic with significant changes in oral intake (copious intake of water or use of other lubricants, diet 2 limited to purees and / or moist and soft foods); Production of unstimulated saliva between 0.1 and $0.2 \mathrm{ml} /$ min;

Level Symptoms that lead to inability to feed orally; need for intravenous fluids, enteral or parenteral feeding; $3 \quad$ Production of unstimulated saliva $<0.1 \mathrm{ml} / \mathrm{min}$.

Xerostomia was only evaluated in children aged 6 years and older and adolescents.

Mucositis diagnosis was made through clinical examination, in which the appearance of the oral mucosa was evaluated. No classification of its severity was made; it was only considered absent or present if there was a change in the mucosa in any of the levels (discoloration, erythema, pseudomembrane and deep ulceration) of disease severity proposed by WHO ${ }^{13}$.

Oral complications oral candidiasis, herpes simplex and canker sore were evaluated by visual clinical examination.

\section{Data analysis}

Descriptive data analysis was performed. The association between sociodemographic variables and oral manifestations was verified using Fisher's exact test. The chance of a sociodemographic variable influencing the increase or decrease of oral manifestations was calculated by OR. Significance level of $5 \%$ was adopted. The statistical package SPSS version 21 was used for analysis.

All parents or guardians of the participants signed the consent form and previously clarified data collection. The study was approved on 20 February 2013 by the Research Ethics Committee of the Health Sciences Center (Health Sciences Center) of the Federal University of Espirito Santo (Federal University of Espirito Santo - UFES) by the number opinion 201,117.

\section{Results}


Between April 2013 and April 2014, a total of 66 children and adolescents were admitted to HEINSG with cancer diagnosis to undergo chemotherapy. In 15 of these patients, the approach was not possible (Fig. 1). The study population consisted of 51 individuals.

Table 1 describes the sociodemographic characteristics of the children and adolescents participating in the study. It was observed that the majority of patients are in the age range of $1-4$ years $(31.4 \%)$, males $(60.8 \%)$, live in cities in the inner state of ES (45.1\%), belonging to socioeconomic class C (60.8\%), according to Brazil (2012), attend school (68.6\%), have up to four years of study (21.5\%) and up to eight years of study $(21.5 \%)$.

Also according to Table 1, the family head is the father in $62.7 \%$. Regarding schooling, it was observed that the family head in $43.1 \%$ has between four and eight years of schooling, the majority of mothers studied more than 12 years (37.2\%).

Table 1 also showed that the majority of individuals (37.7\%) received leukemia as a diagnosis.

Table 1. Description of sociodemographic data of children and adolescents participating in the study, 2013 and 2014 , HEINSG 


\begin{tabular}{|c|c|c|c|}
\hline \multicolumn{2}{|l|}{ Category } & \multirow{2}{*}{$\begin{array}{l}\text { n } \\
6\end{array}$} & \multirow{2}{*}{$\begin{array}{l}\% \\
11.8\end{array}$} \\
\hline & Under 1 year & & \\
\hline \multirow[t]{4}{*}{ Age group } & 1 to 4 years & 16 & 31.4 \\
\hline & 5 to 9 years & 11 & 21.6 \\
\hline & 10 to 14 years & 7 & 13.7 \\
\hline & 15 to 18 years & 11 & 21.6 \\
\hline \multirow[t]{2}{*}{ Sex } & Male & 31 & 60.8 \\
\hline & Female & 20 & 39.2 \\
\hline \multirow[t]{4}{*}{ City of residence / Place of residence } & Grande Vitória - ES & 22 & 43.1 \\
\hline & Inner cities - ES & 23 & 45.1 \\
\hline & Bahia & 4 & 7.8 \\
\hline & Minas Gerais & 2 & 3.9 \\
\hline \multirow[t]{4}{*}{ Socioeconomic class } & B & 8 & 15.7 \\
\hline & C & 31 & 60.8 \\
\hline & $\mathrm{D}$ & 11 & 21.6 \\
\hline & $E$ & 1 & 2.0 \\
\hline \multirow[t]{4}{*}{ Family head } & Father & 32 & 62.7 \\
\hline & Mother & 3 & 5.9 \\
\hline & Grandfather / Grandmother & 4 & 7.8 \\
\hline & Others & 12 & 23.5 \\
\hline \multirow[t]{4}{*}{ Schooling of the family head } & $0-4$ years of study & 4 & 7.8 \\
\hline & $4-8$ years of study & 22 & 43.1 \\
\hline & $8-12$ years of study & 12 & 23.5 \\
\hline & More than 12 years of study & 13 & 25.4 \\
\hline \multirow{5}{*}{$\begin{array}{l}\text { Maternal schooling } \\
\text { Years of study }\end{array}$} & $0-4$ years of study & 3 & 5.9 \\
\hline & $4-8$ years of study & 17 & 33.3 \\
\hline & $8-12$ years of study & 11 & 21.5 \\
\hline & More than 12 years of study & 19 & 37.2 \\
\hline & No information & 1 & 2.0 \\
\hline \multirow[t]{4}{*}{ Diagnostic } & Leukemia & 21 & 41.2 \\
\hline & Lymphomas & 10 & 19.6 \\
\hline & Renal tumors & 6 & 11.8 \\
\hline & CNS Tumors & 4 & 7.8 \\
\hline
\end{tabular}




\begin{tabular}{|lllc|}
\hline Category & $\mathbf{n}$ & \% \\
\hline Tumors sympathetic NS & 3 & 5.9 \\
\hline Bone tumors & 2 & 3.9 \\
\hline Others & 5 & 9.8 \\
\hline & & \\
\hline
\end{tabular}

In Table 2 that describes data on the use of dental services are described, it can be observed that $72.5 \%$ did not seek the dentist in the last six months, but $54.9 \%$ sought the dentist at some time in their lives, most of them had toothbrushes (92.2\%), used toothpaste (88.2\%) during tooth brushing and performed tooth brushing twice a day (39.2\%).

Table 2. Description of data on the use of dental services of children and adolescents participating in the study

\begin{tabular}{|c|c|c|c|}
\hline & & $\mathbf{n}$ & $\%$ \\
\hline \multirow[t]{4}{*}{ Visited the dentist in the last 6 months? } & Yes & 13 & 25.5 \\
\hline & No & 37 & 72.5 \\
\hline & Total & 50 & 98.0 \\
\hline & No information & 1 & 2.0 \\
\hline \multirow[t]{2}{*}{ Have you ever visited the dentist? } & Yes & 28 & 54.9 \\
\hline & No & 23 & 45.1 \\
\hline \multirow[t]{2}{*}{ Do you have a toothbrush? } & Yes & 47 & 92.2 \\
\hline & No & 4 & 7.8 \\
\hline \multirow[t]{2}{*}{ Do you use toothpaste? } & Yes & 45 & 88.2 \\
\hline & No & 6 & 11.8 \\
\hline \multirow[t]{5}{*}{ How many brushes per day in the last week? } & None & 12 & 23.5 \\
\hline & Once & 8 & 15.7 \\
\hline & 2 times & 20 & 39.2 \\
\hline & 3 times & 9 & 17.6 \\
\hline & 4 times or more & 2 & 3.9 \\
\hline
\end{tabular}

The table below shows that xerostomia was the most common oral disease found in the examination of individuals participating in the study, followed by dental caries. 


\begin{tabular}{|lll|}
\hline Table 3. Percentage of oral diseases found in the 1st moment clinical examination, Vitória, ES. \\
\hline & 1 st moment & \\
\hline & $\mathrm{n}$ & 3.9 \\
\hline Mucositis & 2 & 31.0 \\
\hline Xerostomia & 9 & 2.0 \\
\hline Canker sore & 1 & 3.9 \\
\hline Candidiasis & 2 & 25.4 \\
\hline Dental caries & 13 & \\
\hline Note: Xerostomia evaluated only in individuals over 6 years of age. & \\
\hline
\end{tabular}

Table 4 used the Fisher's exact test to calculate the existence of association between dental caries and sociodemographic and clinical variables. A statistically significant association was found between dental caries and the lowest number of tooth brushing per day. Tooth brushing is therefore a protective factor against caries, since individuals who brush their teeth three times or more a day are approximately $89 \%$ less likely to develop this disease. A statistically significant association was also observed between lower maternal schooling and higher number of individuals with caries, so maternal schooling is a protective factor against caries, since individuals whose mothers have higher schooling are $82 \%$ less likely to develop this lesion.

Table 4. Association between dental caries disease and sociodemographic and clinical variables 


\begin{tabular}{|c|c|c|c|c|c|c|c|}
\hline & & \multicolumn{2}{|c|}{$\begin{array}{l}\text { Number of individuals } \\
\text { with dental caries }\end{array}$} & \multirow[t]{2}{*}{$\begin{array}{l}\mathrm{p}- \\
\text { value* }^{*}\end{array}$} & \multirow[t]{2}{*}{ OR } & \multicolumn{2}{|l|}{$95 \% \mathrm{Cl}$} \\
\hline & & No & Yes & & & Lower & Upper \\
\hline \multirow[t]{2}{*}{ Age group } & $\begin{array}{l}\text { Younger than or } \\
\text { equal to } 9 \text { years }\end{array}$ & 24 & 9 & \multirow[t]{2}{*}{0.750} & \multirow[t]{2}{*}{0.762} & \multirow[t]{2}{*}{0.198} & \multirow[t]{2}{*}{2.938} \\
\hline & $10-18$ years & 14 & 4 & & & & \\
\hline \multirow[t]{2}{*}{ Sex } & Male & 22 & 9 & \multirow[t]{2}{*}{0.529} & \multirow[t]{2}{*}{0.611} & \multirow[t]{2}{*}{0.160} & \multirow[t]{2}{*}{2.339} \\
\hline & Female & 16 & 4 & & & & \\
\hline \multirow{2}{*}{$\begin{array}{l}\text { City of residence / Place of } \\
\text { residence }\end{array}$} & Grande Vitória - ES & 16 & 6 & \multirow[t]{2}{*}{0.999} & \multirow[t]{2}{*}{0.848} & \multirow[t]{2}{*}{0.239} & \multirow[t]{2}{*}{3.010} \\
\hline & Other regions & 22 & 7 & & & & \\
\hline \multirow[t]{2}{*}{ Socioeconomic class } & $\mathrm{A} / \mathrm{B} / \mathrm{C}$ & 31 & 8 & \multirow[t]{2}{*}{0.254} & \multirow[t]{2}{*}{2.768} & \multirow[t]{2}{*}{0.692} & \multirow[t]{2}{*}{11.609} \\
\hline & $D / E$ & 7 & 5 & & & & \\
\hline \multirow{2}{*}{$\begin{array}{l}\text { How many brushes per day } \\
\text { in the last week? }\end{array}$} & None / once / twice & 92 & 12 & \multirow[t]{2}{*}{0.016} & \multirow[t]{2}{*}{0.114} & \multirow[t]{2}{*}{0.015} & \multirow[t]{2}{*}{0.902} \\
\hline & Three times or more & 67 & 1 & & & & \\
\hline \multirow[t]{2}{*}{ Diagnostic } & $\begin{array}{l}\text { Leukemia / } \\
\text { Lymphoma }\end{array}$ & 22 & 9 & \multirow[t]{2}{*}{0.529} & \multirow[t]{2}{*}{0.611} & \multirow[t]{2}{*}{0.160} & \multirow[t]{2}{*}{2.339} \\
\hline & Other diagnostics & 16 & 4 & & & & \\
\hline \multirow[t]{2}{*}{$\begin{array}{l}\text { Schooling of the family } \\
\text { head }\end{array}$} & $\begin{array}{l}\text { Up to } 8 \text { years of } \\
\text { study }\end{array}$ & 18 & 8 & \multirow[t]{2}{*}{0.523} & 0.563 & 0.155 & 2.035 \\
\hline & $\begin{array}{l}\text { More than } 8 \text { years } \\
\text { of study }\end{array}$ & 20 & 5 & & & & \\
\hline Maternal schooling & $\begin{array}{l}\text { Up to } 8 \text { years of } \\
\text { study }\end{array}$ & 11 & 9 & 0.021 & 0.188 & 0.048 & 0.742 \\
\hline & $\begin{array}{l}\text { More than } 8 \text { years } \\
\text { of study }\end{array}$ & 26 & 4 & & & & \\
\hline
\end{tabular}

\section{Discussion}

Regarding sex, a predominance of males in cancer patients was observed in this study, which is in agreement with the results of several national and international studies 1,9,10,15,16,17,18. In an international study, the number of children and adolescents with cancer was equal for both sexes ${ }^{19}$. This may indicate fragility in body constitution relative to males or an association with genetic predisposition factors linked to the $\mathrm{X}$ chromosome ${ }^{14}$.

In this study, there was a predominance of individuals aged 1-4 years, which is in agreement with the findings of a study conducted in Espírito Santo ${ }^{19}$ and another in Salvador, Bahia ${ }^{14}$, but different from a study conducted in Recife (Brazil) ${ }^{9}$. This predominance of cases of malignant neoplasms in early age groups should be taken into account, since the younger the patient, the greater the possibility of chemotherapeutic treatment affecting the oral cavity 5,7 .

Regarding the clinical profile, a large number of cases of leukemias was observed in this study, a similar result was found in several studies $1,9,15,20$. This result is extremely important in the multidisciplinary planning of the treatment of these 
patients, since this hematological neoplasia is characterized by a high incidence of oral manifestations at the time of diagnosis and during treatment ${ }^{17}$.

Regarding the caries-dependent variable, it was observed that the clinical examination was performed on individuals who had just received the diagnosis of cancer, i.e., they were not performing or had only begun cancer treatment ( 2 days of treatment), which does not cause any changes in the caries-related examination and therefore could not be compared to individuals undergoing chemotherapy, so they were compared to the general population in this variable. The results of this study showed a prevalence of $25.4 \%$ of individuals with dental caries in the age groups analyzed, being in agreement with the results of an expressive number of studies ${ }^{11,22,23}$, which found higher prevalence of individuals with the disease. SB Brasil, which is the largest national oral health research, clearly shows that, according to WHO classification, between 2003 and 2010, the percentage of individuals with caries significantly reduced in the country in all age groups evaluated up to 19 years old. At the age of 5, the number of individuals with caries decreased from $64.68 \%$ (2003) to $53.4 \%$ (2010), at 12 years, it reduced from $74.43 \%$ (2003) to $56.5 \%$ (2010) and at 15-19 years of age, the percentage reduced from $89.59 \%$ (2003) to $76.1 \%$ (2010). In 2003, Brazil presented a condition classified as having a prevalence of carious lesions in the population, and in 2010, it presented a condition with low caries prevalence. One factor that may explain this lower prevalence of the disease is the fact that most of the study sample belongs to socioeconomic class $\mathrm{C}$, since it is known that there is a higher percentage of individuals who present carious lesions in situations of worse socioeconomic conditions that would be represented by classes $D$ and $E$, which appear in very small number in this research.

There was no statistically significant association between caries and socioeconomic class, possibly due to the predominance of socioeconomic class $\mathrm{C}$, inexistence of class $\mathrm{A}$ and almost nonexistence of class $\mathrm{E}$, which made it impossible to compare classes.

There was a statistically significant association in this study between individuals with caries and the number of toothbrushes per day, that is, the fewer brushings, the greater the number of individuals with caries. It was also observed a statistically significant association between maternal schooling and individuals with caries, that is, the lower the maternal schooling, the greater the number of individuals with caries; this finding has been common in most studies in literature $23,24,25,26,27$, showing that the dental caries disease is linked to the numerous situations of greater social deprivation.

The results of this research related to dental caries confirm that the individual's social insertion has a direct influence on the prevalence of dental caries ${ }^{25,29}$. In this sense, individuals with higher schooling level tend to brush their teeth more often, and their children are inserted in the process of dental hygiene earlier, which has a significant impact on oral health 24 . One of the factors that explain the decline of caries is the increase in access to fluoride toothpaste, so not only the mechanical movement of tooth brushing that disorganizes plaque, reducing the risk of carious lesion development, but also the contact of dental elements with fluoride in this process may explain the association between greater amount of caries and less frequent brushing 26 .

Tests of association between xerostomia and sociodemographic variables were also performed; however, no variables presented statistical significance. The other oral diseases such as oral mucositis, oral candidiasis and canker sore presented very low prevalence, therefore no association tests were performed.

Oral and dental complications in cancer patients can be attributed to malignancies themselves or cancer therapy ${ }^{30}$, and can be classified as primary, secondary and tertiary. Primary oral manifestations occur due to infiltration of oral tissues by leukemic cells, secondary ones are associated with thrombocytopenia and immunosuppression caused by leukemia and tertiary are the result of chemotherapy. Infections and worsening of preexisting oral diseases may also occur ${ }^{17}$, which was observed in this study, since oral diseases were found in individuals before starting chemotherapy, which is in agreement with other studies 17,18 . 
The sample size represents a study limitation; however, in Brazil, the percentage of pediatric tumors observed is $1-3 \%$, characterizing a low prevalence of this disease, making it difficult to allocate a large number of individuals in a primary data study.

The results of this study showed that even before starting chemotherapy, some patients already presented caries and other oral diseases, so this group deserves special attention in relation to oral health, since in patients with poor oral hygiene and preexisting odontogenic infection, there is a marked risk of development of oral infections during the periods of myelosuppression induced by chemotherapy ${ }^{5}$.

Patients with better oral health conditions and satisfactory oral hygiene exhibit fewer manifestations and have faster clinical course ${ }^{17}$.

\section{Conclusion}

Before starting the chemotherapeutic treatment, some individuals already had oral diseases and also had dental caries that showed a statistically significant association with low maternal schooling and few toothbrushes per day. This information is valuable in planning the multidisciplinary treatment of these patients, since they present poor oral condition and tend to develop more oral manifestations during CT.

Dental professionals should be present in the multidisciplinary oncology team and work together so that the initial dental assessment is done properly, thus, the oral health professional can elaborate and suggest a plan of oral preparation with the purpose of reducing the risks of future oral complications resulting from oncological treatment, promoting oral health and a better quality of life for these patients.

\section{Declarations}

\section{Compliance with Ethical Standards}

Ethical approval: All parents or guardians of the participants signed the consent form and previously clarified data collection. The study was approved on 20 February 2013 by the Research Ethics Committee of the Health Sciences Center (Health Sciences Center) of the Federal University of Espirito Santo (Federal University of Espirito Santo - UFES) by the number opinion 201,117 .

Informed consent: All parents or guardians of children and adolescents who participated in the study received prior information about the purpose of the study and signed an informed consent form.

\section{Consent for publication}

Consent for publication is included in the consent to participate in research.

\section{Competing interests:}

$\mathrm{Ms}^{\mathrm{a}}$ Deise Berger Velten declares that he has no conflict of interest.

Dra Eliana Zandonade declares that he has no conflict of interest.

Dra ${ }^{a}$ Maria Helena Monteiro de Barros Miotto declares that he has no conflict of interest.

Funding: The research received no funding, so all expenses were paid by the authors themselves. 
Authors' Contributions: Deise Berger Velten: a) the design and design, analysis and interpretation of data, b) drafting the article or revising it critically e c) approval of the version to be published. Eliana Zandonade: a) the design and design, analysis and interpretation of data, b) revising it critically. Maria Helena Monteiro de Barros Miotto: a) the design and design, analysis and interpretation of data, b) revising it critically e c) approval of the version to be published.

\section{Acknowledgements:}

We declare that there was no significant contribution in addition to the authors themselves in the making of the article.

\section{Availability of data and materials}

The data of this manuscript is available and can be accessed by request at deisebv82@gmail.com.

\section{References}

1. Barbosa AM, Ribeiro DM, Caldo-Teixeira AS. Conhecimentos e práticas em saúde bucal com crianças hospitalizadas com câncer. CiêncSaudeColet, 2010; 15(Supl.1):1113-22. [acessado 2017 jun 13]. Disponível em:

http://www.scielosp.org/pdf/csc/v15s1/019.pdf.

2. Ministério da Saúde. Secretaria Nacional de Assistência à Saúde. Instituto Nacional do Câncer. Estimativa 2010: incidência do câncer no Brasil. Rio de Janeiro: INCA, 2009. [acessado 2017 jun 14]. Disponível em:

http://www2.inca.gov.br/wps/wcm/connect/agencianoticias/site/home/noticias/2009/lancamento_estimativa_2010.

3. Instituto Nacional Do Câncer. Estimativa/2014: incidência do câncer no Brasil. Rio de Janeiro: INCA 2014. [acessado 2017 abr 20]. Disponível em: http://www.inca.gov.br/estimativa/2014/estimativa-24042014.pdf.

4. Instituto Nacional do Câncer. Coordenação de Prevenção e Vigilância do Câncer. Câncer na criança e no adolescente no Brasil. Dados dos Registros de Base Populacional. Rio de Janeiro: Sociedade Brasileira de Oncologia Pediátrica (SOBOPE), 2008. [acessado 2017 jun 23]. Disponível em:

http://www1.inca.gov.br/tumores_infantis/pdf/livro_tumores_infantis_0904.pdf.

5. Sonis ST, Fazio RC, Fang L. Complicações bucais da terapia do câncer. In: Sonis ST, Fazio RC, Fang L. Princípios e prática de medicina oral. 2 ed; Rio de Janeiro:Guanabara Koogan; 1996:358-83.

6. Simões CA, Castro JFL, Cazal C. Cândida oral como fator agravante da mucosite radioinduzida. RevBrasCancerol, $2011 ; 57(1): 23-29$.

7. Martins ACM, Caçador NP, Gaeti WP. Complicações bucais da quimioterapia antineoplásica. Acta Scientiarum. 2002; 4(3):663-70. [acessado 2017 maio 20]. Disponível em: http://eduem.uem.br/ojs/index.php/ActaSciHealthSci/article/viewFile/2481/1661.

8. Sasada INV, Cancino CMH, Petersen RC, Hellwing I, Dillenburg CS. Prevenção de intercorrênciasestomatológicas em oncologia pediátrica. RFO, 2015; 20(1):105-09, jan./abr.

9. Albuquerque RA, Morais VLL, Sobral APV. Avaliação clínica da frequência de complicações orais e sua relação com a qualidade de higiene bucal em pacientes pediátricos submetidos a tratamento antineoplásico. ArqOdontol, 2007; 43(2):9-16.

10. Arisawa EAL, Silva CMOM, Cardoso CAC, Lemos NRPL, Pinto MC. Efeitos colaterais da terapia antitumoral em pacientes submetidos à quimio e à radioterapia. Revbiocienc, 2005; 11(1-2):55-61, jan./jun. 
11. Brasil 2010. Pesquisa nacional de saúde bucal. Resultados principais, 2012. [acessado 2014 jul 10]. Disponível em: http://bvsms.saude.gov.br/bvs/publicacoes/pesquisa_nacional_saude_bucal.pdf.

12. Feio M, Sapeta P. Xerostomia em cuidados paliativos. Acta Med Port. 2005; 18:459-66.

13. Organização Mundial de Saúde. Nacional CancerInstitute. Common Terminology Criteria for Adverse Events v. 3.0, agosto de 2006. [acessado 2012 set 2]. Disponível em:

http://ctep.cancer.gov/protocolDevelopment/electronic_applications/docs/ctcaev3.pdf.

14. Diniz AB, Regis CA, Brito NP, Conceição LS, Moreira LMA. Perfil epidemiológico do câncer infantil em população atendida por uma unidade de oncologia pediátrica em Salvador-Bahia. Rev ciêncméd. biol, 2005; 4(2):131-39.

15. Otmani N, Alami R, Hessissen L, Mokhtari A, Soulaymani A, Khattab. Determinants of severe oral mucositis in paediatric cancer patients: a prospective study. Int j paediatr dent, 2011; 21:210-16.

16. Cheng KKF, Lee V, Li CH, Goggins W, Thompson DR, Yuen HL et al. Incidence and risk factors of oral mucositis in paediatric and adolescent patients undergoing chemotherapy. Oral Oncology, 2011; 47:153-62.

17. Trindade AKF, De Biase RCCG, Filho GG, Pereira BC, Sousa EMD, Queiroga AS. Manifestações orais em pacientes pediátricos leucêmicos. ArqOdontol, 2009; 41(1):22-29.

18. Santos VI, Anbinder AL, Cavalcante ASR. Leucemia no paciente pediátrico: atuação odontológica. CiencOdontol Bras, 2003; 6(2):49-57.

19. Zouain-Figueiredo GP, Zandonade E, Amorim MHC. Cancer survival among children and adolescents al a state referral hospital in southeastern Brazil. RevBras Saúde MaternInfant, 2013; 13(4);335-44 v. 13, n. 4, p. 335-344, out./dez.

20. Alberth M, Majoros L, Kovalecz G, Borbás E, Szegedi I, Márton IJ et al. Significance of oral cândida infections in children with cancer. Patholoncol res, 2006; 12(4):237-41.

21. Cheng KKF, Molassiotis A, Chang AM, Wai WC, Cheung SS. Evaluation of an oral care protocol intervention in the prevention of chemotherapy-induced oral mucositis in paediatric cancer patients. Eur j cancer, 2001; 37:2056-63.

22. Sartori LA. Prevalência da doençacárieem escolares de 5 a 14 anos, na cidade de Alfenas-MG. RevUnivAlfenas, 1999; 5:1-10.

23. Brasil 2003. Projeto SB Brasil 2003. Condições de saúde bucal da população brasileira 2002-2003. Resultados Principais, 2004. [acessado 2014 jul 10]. Disponível em: http://cfo.org.br/wp-

content/uploads/2009/10/04_0347_M.pdf,

24. Baldani MH, Narvai PC, Antunes JLF. Cárie dentária e condições socioeconômicas no Estado do Paraná, Brasil, 1996. Cad Saúde Pública. 2002; 18(3): 755-63.

25. Peres KGA, Bastos JRM, Latorre MRDO. Severidade de cárie em crianças e relação com aspectos sociais e comportamentais. Rev saúde pública. 2000; 34(4):402-8.

26. Musso VF, Zandonade E, Emmerich AO. Desigualdades na distribuição da cárie dentária aos 12 anos no Brasil. RevBrasPesq Saúde. 2013; 15(2):64-72.

27. Narvai PC, Frazão P, Roncalli AG, Antunes JL. Cárie dentária no Brasil: declínio, polarização, iniquidade e exclusão social. Pan am j publichealth, 2006; 19(6):385-93.

Page 13/14 
28. Boing AF, Peres MA, Kovaleski DF, Zange SE, Antunes JLF. Estratificação socioeconômica em estudos epidemiológicos de cárie dentária e doenças periodontais: características da produção na década de 90. Cad Saúde Pública. 2005; 21(3):673-78.

29. Nadanovsky PO. Declínio da cárie. In: Saúde Bucal Coletiva, Pinto VG, São Paulo: Santos, 341-51, 2008.

30. Mcgaw WT, Alberta ABE. Oral complications of acute leukemia: Profhylactic impact of a chlorhexidine mouth rinse regimen. Oral Surg, 1985:275-80.

\section{Figures}

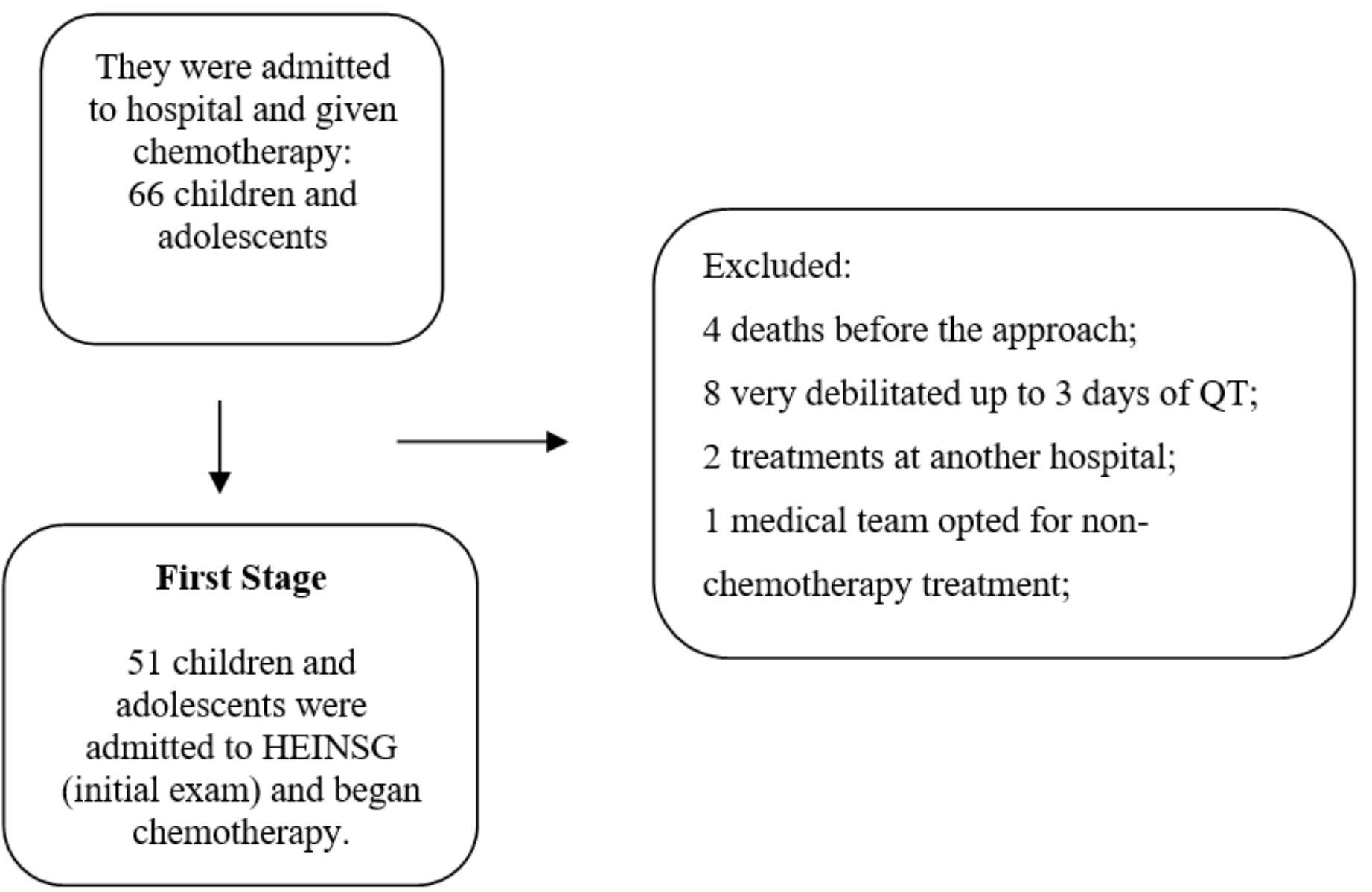

Figure 1

Losses during the follow-up of patients in HEINSG 